\title{
THE LOCAL CONSTRUCTION OF RELIGIOUS BLASPHEMY IN EAST JAVA
}

\author{
M. Syamsul Huda \\ UIN Sunan Ampel Surabaya - Indonesia | m.syamsul.huda@uinsby.ac.id
}

\begin{abstract}
The blasphemy case of Basuki Tjahaja Purnama, known as Ahok, who is a Christian and was Jakarta's nonMuslim governor, has sparked different reactions among Muslim groups in Indonesia. Reactions of Muslim groups of different persuasion in East Java will be highlighted in this article. Two theological constructions emerged out of this case, namely textual-normative and moderate-substantive constructions. This article aims to identify theological construction and social actions as normative propositions and actions of Muslim groups in East Java. To comprehend the concepts and responses through the article, several leaders of the Muslim roups such as FPI (Front Pembela Islam), HTI (Hizb al-Tahrir Indonesia), FUI (Forum Umat Islam), MMI (Majlis Mujahidin Indonesia), Al-Irsyad, FS-LDK (Forum Studi Lembaga Dakwah Kampus), NU (Nahdlatul Ulama) and Muhammadiyah were interviewed. The article finds that moderate and rational theological concept of blasphemy is coined by major Muslim groups especially NU and Muhammadiyah which prioritize greater national interest, whereas other Muslim roups, especially those with literal interpretation, promote political identity vis-à-vis other religious groups.
\end{abstract}

Keywords: Blasphemy, religious construction, theology.

\section{Introduction}

Indonesia became the center of world attention during the campaign for the Governor of Jakarta general election held in February 2017. The election was considered to be the dirtiest ${ }^{1}$, polarizing ${ }^{2}$ and

\footnotetext{
1 M. D. Conover, J. Ratkiewicz, M. Francisco, B. Goncalves, and A. Flammini, "Political Polarization on Twitter," Proceedings of the Fifth International AAAI Conference on Weblogs and Social Media, 2011.

2 James I. Lengle, Diana Owen, and Molly W. Sonner "Divisive Nominating Mechanisms and Democratic Party Electoral Prospects," The Journal of Politics, 57, 2 (May, 1995): pp. 370-383.
} 
most divisive in which the candidates Anies Baswedan (Anies) Sandiaga Uno (Sandi) defeated the candidates Basuki Tjahaja Purnama (Ahok)-Jarot Saiful Hidayat (Jarot). In this election, Anis-Sandi was supported by several parties, notably Partai Gerindra, Partai Keadilan Sejatera (PKS, Justice and Prosperous Party) and Partai Amanat Nasional (PAN, National Mandate Party). The campaign strategy of Anis-Sandi use religious sentiments as Basuki Tjahaja Purnama is a Protestant. This strategy intensified especially after Ahok's statement in Kepulauan Seribu on 27th of September 2016 that led to blasphemy accusation against him. The strategy was seemingly responded by grassroots groups throughout the country by reflecting religious and ethnic sentiments into the political issue. Certainly, this blasphemy case further tainted Indonesian record of religious freedom. ${ }^{3}$

The practice of religious and political identity ${ }^{4}$ is used to defend Islam to put Ahok behind bar by mobilizing Islamic mass organizations in some major cities on charges of religious blasphemy against Ahok as he accused that some clerics had misled Muslim community using a verse in the Holy Qur'an, namely chapter alMaidah verse 51. the verse itself contain a prohibition for Muslims to take Jews and Christians as wali. Wali is an Arabic word with multiple meanings, namely helper, supporter, benefactor, sponsor, friend, close associate, relative, patron, protector legal guardian, and saint. ${ }^{5}$ However, the official translation of the Holy Quran issued by the Indonesian Ministry of Religious Affairs says that wali in that verse is pemimpin (Indonesian word for leader or ruler). ${ }^{6}$ The fact that many people who opposed his reelection use this meaning in the gubernatorial election campaign against Ahok, has triggered Ahok's controversial statement.

Terminologically, blasphemy refers to opposition to sacred religious symbols such as religion, religious leaders, religious

\footnotetext{
3 Paul Marshall, "The Ambiguities of Religious Freedom in Indonesia," The Review of Faith \& International Affairs, 16, 1 (2018): pp. 85-96.

4 Samina Yasmeen "Pakistan, militancy and identity: parallel struggles," Australian Journal of International Affairs, 67, 2 (2013): pp. 157-175.

${ }^{5}$ Hans Wehr, A Dictionary of Modern Written Arabic (Ithaca: Spoken Language Services, Inc, 1976), p. 1100

${ }^{6}$ Ministry of Religious Affairs Republic Indonesia, Alqur'an dan Terjemabnya (Madinah Al-Munawwarah: Mujamma' Al-Malik Fahd Li Thiba At Al Mush-haf Asy-Syarif, 1993), p. 169.
} 
scriptures. ${ }^{7}$ The situation over Ahok's Blasphemous statement sparked more heated controversy as Majelis Ulama Indonesia (MUI, the Indonesian Ulama Council) ${ }^{8}$ issued a fatwa (a non-binding legal opinion in Islamic law) declaring: "The statement of Basuki Tjahaja Purnama is categorized as: (1) defaming the holy Qur'an and/or (2) defaming ulama who have legal authority in Islam". ${ }^{9}$ Such a statement of MUI eventually triggered some hardline Muslims to form a movement called Gerakan Nasional Pengawal Fatwa MUI (GNPF MUI, National Movement for Fatwa Guarding). ${ }^{10}$ GNPF then initiated and mobilized several demonstrations-eventually referring to popular movements of 411 and 212-forcing the court to put Ahok on trial, and eventually sent him behind bars.

However, in response to the case of religious blasphemy by Ahok, in terms of religious institutions, Muslims have different theological views. The first group comes with textual ${ }^{11}$ and normative perspectives that Ahok has blasphemed Islam by defaming 'ulamā' and the Holy Qur'an. This group is specifically affiliated with hardliners within MUI and its fatwa supporters. Whereas, the second group-apparently affiliated with Nahdatul Ulama (NU) and Muhamadiyyah holds a

\footnotetext{
7 Siti Aminah, et al, "Pemantauan Kasus-Kasus Penodaan Agama di Indonesia Periode 2012-2014," Jurnal Keadilan Sosial, 5 (2015), p. 26.

${ }^{8}$ MUI was established by government during Suharto's regime in 1975 to channel government's voice on Islam. It is partly funded by government. Thus, from the beginning, the political nature of MUI is prevalent. It is comprised of Muslims from different streams in Indonesia, moderate and hardline Muslims alike. Its main function is to issue fatwa on several matters, including on guarding Islamic orthodoxy practices, sharia banking, and product (food, drug, cosmetics, etc.) lawfulness. The voice of MUI depends on which groups have effective control over its functions. Nowadays, hardliners have strong presence within MUI. For further account on MUI as a fatwa issuing body, please read for instance M. Atho Mudzhar, "The Legal Reasoning and Socio-Legal Impact of the Fatwãs of the Council of Indonesian Ulama on Economic Issues," Abkam, 13, 1 (January 2013), pp 9-20 and Syafiq Hasyim, "Majelis Ulama Indonesia and pluralism in Indonesia," Philosophy \& Social Criticism, 41, 4-5 (2015), pp. 487-495.

9 "Pendapat Dan Sikap Keagamaan Majelis Ulama Indonesia Terkait Pernyataan Basuki Tjahaya Purnama," https://mui.or.id/berita/10590/pendapat-dan-sikapkeagamaan-mui-terkait-pernyataan-basuki-tjahaja-purnama/, 20 February 2017.

10 Rangga Kusumo and Hurriyah, "Populisme Islam di Indonesia: Studi Kasus Aksi Bela Islam oleh GNPF-MUI Tahun 2016-2017," Jurnal Politik, 4, 1 (2018), pp. 96-101.

${ }^{11}$ Mark. R. Woodward, “The 'Slametan': Textual Knowledge and Ritual Performance in Central Javanese Islam,” History of Religions, 28, 1 (1988), pp. 54-89.
} 
formal juridical ${ }^{12}$ view which assesses the case of Ahok not as a religious issue but rather a civil case. Thus, it is the case of law enforcement officials to deal with.

Apart from the pros and cons of Ahok's case, this phenomenon exhibits social facts of people's collectivity and solidarity dimension ${ }^{13}$ triggering religious social movements. It means that the case of Ahok resulted in major problem which is not only a matter of political and religious context, but it also indicates the context of Muslim solidarity and collectivity. ${ }^{14}$ Nevertheless, Emile Durkheim protested blasphemy based on religious drives in which Islam has bound the followers, ${ }^{15}$ despite of different traditions and customs.

The issue of religious blasphemy, both in the past and present, has made people unite under religious concerns. In the past, blasphemy refers to public concerns. Whereas, blasphemy in today's issue refers to political-pragmatic ${ }^{16}$ concerns especially related to political general elections. In other words, in the past religious blasphemy concerned public (Muslims) solidarity, whereas today, it concerns sectarian political solidarity.

In East Java alone, especially in Surabaya as the capital city of the province, many supporters of Muslim groups involve in a wide range of street demonstrations during the investigation of Ahok's case until eventually taken to court. Some Muslim roups, especially those with hardline approach to Islam, frequently involved in various actions in East Java such as FPI, HTI, and smaller organizations like Ikatan Dai Indonesia (IKADI, Indonesian Association of Muslim Preachers). ${ }^{17}$ They also mobilized people who are not affiliated to mass

12 Mark Cammack, "Islamic Law in Indonesia's New Order," International and Comparative Law Quarterly, 38, 1 (1989), pp. 53-73.

13 M. Osa, "Creating Solidarity: the Religious Foundations of the Polish Social Movement," East European Politics \& Societies, 67, 11, 2 (1997): pp. 339-365.

${ }^{14}$ Bradley Lewis, “The Biopsychosocial Model and Philosophic Pragmatism: Is George Engel a Pragmatist? Philosophy,” Psychiatry, \& Psychology, (2007), pp. 299-310.

${ }^{15} \mathrm{~J}$. Haynes, "Religion and international relations in the 21 st century: conflict or cooperation?," Third World Quarterly, 27, 3 (2006), p. 538.

${ }^{16}$ V. Dubljević, "Autonomy is Political, Pragmatic, and Postmetaphysical: A Reply to Open Peer Commentaries on 'Autonomy in Neuroethics'," AJOB Neuroscience, 7, 4 (2016).

17 "Massa Ormas Islam Jatim Demo Minta Ahok Dipejarakan," https://www.tribunnews.com/regional/2017/05/08/massa-ormas-islam-jatim-demo-minta-ahokdipenjarakan, accessed on 8 May 2017. 
organizations such as people of various social networks. However, people who are subscribed to more moderate Islamic organizations such as NU and Muhammadiyah prefer taking neutral position, in a sense that as an organization they never encourage people (the followers) to participate in any demonstration. Nevertheless, though no direct instructions from the organization, quite many people of these two organizations took part in the demonstrations. Though the mobilization of mass movements is not as massive as in Jakarta, some Islamic mass organization actions did take place in many cities in East Java, especially Surabaya. It apparently indicates how religious terms (Islam) strategically influence and inspire islamic mass organizations, especially in the case of blasphemy.

Hence, this article concerns on how Islamic social groups in East Java reformulate religious blasphemy in a broader perspective through formal theological and juridical perspective, for instance, as initiated by NU and Muhammadiyah. This paper will obviously contribute to formulate the definition of religious blasphemy. It will also attempt to identify every single move of religious thought related to political power.

\section{Reviewing The Phenomenon of Religious Blasphemy in Indonesia}

Religious blasphemy is not a novel phenomenon In Indonesia. However, the emergence of a case of religious blasphemy involving the figure of Basuki Tjahaja Purnama (Ahok), back then served as the Governor of Jakarta, the term of blasphemy of religion have additional dimension, politics. The emergence of religious blasphemy phenomenon in Indonesia deals with positive legal instruments which accommodates the religious blasphemy law. As mentioned earlier, Indonesia is one of the world's 50 countries incorporating elements of blasphemy and misdirection in the formulation of state law. Thus, any conduct indicated to be despicable, abusive, defamatory, or offensive to a particular religion, may be directly subject to the law.

Exploring the case of religious blasphemy throughout the history of Indonesia allows us to find many interesting facts. For instance, though the term of religious blasphemy previously did not exist, similar cases had occurred during Dutch colonial period, one of which is the case of Djawi Hiswara newspaper. In 1918, Djawi Hiswara published an article entitled Pertjakapan antara Marto dan Djojo [The conversation 
between Marto and Djojo]. ${ }^{18}$ The article mentioned that the Prophet Muhammad was drinking and enjoying opium. The article instantly ignited Muslim community's emotion. HOS Tjokroaminoto, the leader of Sarikat Islam (SI) urged the masses to demonstrate. A total of 150,000 people from forty-two places across Java and parts of Sumatra gathered to demand the colonial government to put Martodharsono and Djojodikoro into trial. The two gentlemen were then accused by HOS Tjokroaminoto as responsible for the newspaper Djawi Hiswara. ${ }^{19}$

During 1965-2017 periods, 97 cases of blasphemy ${ }^{20}$ were listed. Interestingly, cases of blasphemy have grown even greater after the fall of the New Order regime. Prior to reformation era, only nine cases of blasphemy appeared, but immediately after the reform era, the number of cases of blasphemy in Indonesia increased greatly, 88 cases were noted. Among the blasphemy cases, Islam became the most desecrated religion. The remaining four cases hit Christianity, three cases for Catholicism, and two cases for Hinduism. ${ }^{21}$

Similar to what happened to Djawi Hiswara newspaper, in August 1968, a literary magazine published a novel entitled "Langit Makin Mendung". ${ }^{22}$ The title contradicted to what lied in the content as it told a fictional story of prophet Muhammads whereabouts on earth, that was in Jakarta. ${ }^{23}$ It was revealed in the story that prophet Muhammad accompanied by Gabriel to conduct an investigation to eventually find out why only a few people eligible to enter paradise. During the investigation, the prophet was narrated to commit various adultery acts in Jakarta. In addition, the Prophet was pictured to have been drunk and committed various feuds. This certainly ignited conflicts among muslims.

18 Takashi Shiraishi, Zaman Bergerak Radikalisme Rakyat di Jawa 1912-1926 (Jakarta: Pustaka Utama Grafiti, 1997), p. 144.

19 Ahsanul Alfan, "Gerakan Tentara Kanjeng Nabi Muhammad (TKNM) Tahun 1918,” Jurnal Avatara, 4, 3 (October 2016), p. 1151.

20 Muhammad Dahri, "Tindak Pidana Penodaan Agama di Indonesia: Tinjauan Pengaturan Perundang-Undangan dan Konsep Hukum Islam," Jurnal at-Tafahum, 1, 2 (July-December 2017), p. 65.

21 Ibid., p. 66.

22 HB. Jassin, Heboh Sastra 1968: Suatu Pertanggungjawaban Jakarta: Gunung Agung, 1970), p. 21.

${ }^{23}$ Arum Wahyuningtias, "Upaya HB. Jassin dalam Penyelesaian Polemik Heboh Sastra Cerpen 'Langit Makin Mendung' Karya Kipanjikusmin di Majalah Sastra Tahun 19681970," Jurnal Avatara, 3, 2 (July 2015), p. 237. 
Likewise, the fictional work written in a literary magazine under a pseudonym of Ki Pandji Kusmin which eventually ignited the anger and fury of Indonesian Muslims followed by massive rallies. HB Jassin, the editor and also a prominent literary figure, became the target of growing anger after his refusal to reveal the man behind the pseudonym. HB Jassin insisted to protect the author from the demand of the protesters that the author should be punished by death penalty. Although HB Jassin and the literary magazine had proposed an apology, he was sent for trial and eventually deserved a one-year imprisonment.

Another religious blasphemy was also accused to Arswendo Atmowiloto, a Catholic and, back then, the editor in chief of a wellcirculated tabloid named Monitor. He had to deal with legal case as he was considered to have blasphemed Islam after the tabloid released the results of a reader's survey of popular personality through postcards in which prophet Muhammad was rank $11^{\text {th2 } 2}$ Through the rubric named Kagum, Monitor announced a list of world leaders who obtained most admiration of the readers. According to the list, President Soeharto was number one with 5,003 admirers, BJ Habibi (2,975), the late President Soekarno $(2,662)$, Iwan Fals $(2,431)$. From the 5th to the 10th: Zainudin MZ, Try Sutrisno, Saddam Hussein, Siti Hardiyanti Rukmana, and Atmowiloto himself ranked 10th with 797 admirers. ${ }^{25}$ What triggered anger and emotion of most Indonesian Muslims was when Prophet Muhammad was included in the list, yet unfortunately, even under Atmowiloto, the editor-in-chief of the tabloid.

As the result, criticism came from various media, such as Adil newspaper affiliated to Muhammadiyah with the headlines: Penghinaan terbadap Islam: Di balik. Angket Monitor (Insulting Islam: behind the Monitor Survey). In addition, criticism also came from various Muslim figures and scholars such as Amien Rais and Nurcholish Madjid. After going through a long debate and discussion, Monitor was eventually banned by the government. In addition, Arswendo Atmowiloto himself was brought to court, though he had submitted an official apology. He was found guilty and subject to five years in prison. ${ }^{26}$

\footnotetext{
${ }^{24}$ Mahi M. Hikmat, "Kebebasan Pers Kaitannya dengan Penodaan Terhadap Martabat Agama," Jurnal al-Tsaqâfa, 9, 1 (June 2012), p. 16.

${ }^{25}$ Ibid., p. 16.

${ }^{26}$ Ibid., 16.
} 
In 2006, post-reform era, 41 members of Lembaga Pelayanan Mahasiswa Indonesia (LPMI, Indonesian Student Service Institute) had to deal with the law. ${ }^{27}$ They were accused of holding a music event entitled Prayer Concert at Hotel Asida, Batu, Malang, which was considered to contain elements of insults towards Muslims. As the result, those students had to live their lives behind bars as found guilty by court and subject to 5 years imprisonment.

In 2011, Antonius Richmond Bawengan, a Catholic, had to deal with law for similar case. ${ }^{28} \mathrm{He}$ was accused of insulting religion, especially Catholicism and Islam, after distributing a number of leaflets and books which were deemed as offensive to the practices and elements of particular religious beliefs. The leaflets and books included Bencana Malapetaka Kecelakaan-Selamatkan Diri Dari Dajjal (Disaster Agony Disgrace - Save Yourself from Dajjal), Tiga Sponsor-Tiga AgendaTiga Hasil (Three Sponsors-Three Agendas-Three Results), and Putusan Hakim Bebas (Verdict of not guilty). As the result, Antonius Richmond Bawengan was jailed for 5 years in prison.

Furthermore, in 2012, another case of blasphemy involved Rusgiani, a housewife who was accused of insulting and harassing places of worship of Hindu Bali. It all started when Rusgiani stated: "Tuban tidak bisa datang ke rumah ini, karena Canang ini jijik dan kotor."29 (God cannot come to this house (canang) as it is and dirty and disgusting). Rugiani was eventual reported the authority. After some processes in court, Rusgiani was sent for one year in prison.

The most recent blasphemy case was the one involving the former Governor of DKI Jakarta, Basuki Cahaya Purnama (Ahok). Ahok is subject to a blasphemy law after he cited the verse of 51 al-Maidah of the Holy Quran. In his speech in Pulau Seribu, Ahok stated that Muslims should not be deceived by them (refering to Muslim leaders/politicians) using the verse. ${ }^{30}$ After mostly exposed through

27 “41 Penista Agama Divonis Lima Tahun”, https://nasional.tempo.co/read/107062/41-penista-agama-divonis-lima-tahun.

${ }^{28}$ Nazar Nurdin, "Delik Penodaan Agama Islam di Indonesia," Journal Ibya Ulum AlDin, 19, 1 (2017), p. 131.

29 Martien Herna Susanti, "Menguatkan Karakter Kebangsaan Indonesia di Era Globalisasi," Prosiding Seminar Nasional PKn-Unnes (2017), p. 65.

30 Arie Setyaningrum Pamungkas and Gita Octaviani, "Aksi Bela Islam dan Ruang Publik Muslim: Dari Representasi Daring ke Komunitas Luring," Jurnal Pemikiran Sosiologi, 4, 2 (August 2017), p. 66. 
cyberspace, Ahok was eventually prosecuted before the law. Apart from the controversy and debate that this particular case of Ahok had political interests and even refered to the practice of religious politicization and identity. ${ }^{31}$ Ahok was considered to have insulted the holy book of Muslims, the Quran. Many muslims then demanded, with action popularly known as Aksi Bela Islam (Action for Defending Islam), that Ahok should be sent before law and he was eventually found guilty and was sentenced to two years in prison. ${ }^{32}$

From all the facts above, cases of blasphemy in Indonesia often involve mass mobilization and protests. A study has revealed that out of 97 blasphemy cases, 35 of them did not involve mass, while the other 62 cases involve the pressure of mass. ${ }^{33}$ Hence, it is assumed that most cases of religious blasphemy in Indonesia especially in relation to legal cases was apparently full of political interests so that the law for blasphemy cases in Indonesia was no longer relevant. It is assumed that the legal content of blasphemy was not in line with democracy, especially in favour of individual freedom right. Therefore, the review for legal construction of blasphemy, both theologically and judicially, needs to be undertaken.

\section{Reconstructing Religious Blasphemy in East Java}

Religious blasphemy is one of the crucial issues attract a wide range of attentions, spark debate, even ignite many controversies. This is due to the sensitiveness of the term blasphemy directly related to the religious dimension. In terms of public view, religion is believed as a sacred and holy. ${ }^{34}$ Thus, once a particular religion is desecrated, tainted, and harassed, resistance will likely appear as a form of selfdefense of the adherent of religion. Therefore, on many occasions, mass actions emerged in the name of sanctity and sacredness of their religion.

In relation to this, the religious blasphemy committed by former Governor of Jakarta Province, Ahok was included. The case began

\footnotetext{
31 Ibid., p. 80.

32 “Ahok Divonis Dua Tahun Penjara, Ini Komentar Jokowi," https://nasional.kompas.com/read/2017/05/09/17032111/ahok.divonis.dua.tahun.penjara.ini.komentar.jo kowi.

${ }^{33}$ Dahri, “Tindak Pidana, p. 65.

34 Soerjono Soekanto, Mengenal Tujuh Tokoh Sosiologi (Jakarta: Rajawali Pers, 2002), p. 200.
} 
when Ahok made an official visit to Pulau Seribu in which during the visit, Ahok made a speech. In that speech, he urged the audience not to believe people who deceived voters using the verse of al-Maidah verse 51 for not vote for him in gubernatorial election. ${ }^{35}$ The word 'deceived' sparked anger among muslim community. Ahok eventually dealt with law. Though many considered it was politically charged, ${ }^{36}$ the fact that Ahok's statement could be interpreted as blasphemy towards Islam cannot be denied. Therefore, Ahok eventually met the legal certainty that resulting in imprisonment for him.

In many cases, the blasphemy crime such as the Ahok case is often followed by a large number of mass actions. The actions generally contained condemnation as well as demands to process the perpetrator before the law. While some major Muslim roups with a large number of membership such as NU and Muhammadiyah did not participate in the protests, several smaller yet eloquent Islamic groups such as FPI, HTI, FUI, MMI, Al-Irsyad, FS-LDK, Wahdah Islamiyah, Intellectual and Young Ulama Councils, ${ }^{37}$ and many other groups took part. In addition, some members of NU and Muhammadiyah or people who are affiliated to these two major organizations also joined the protests. Mass protests then spread out not only at the capital city of Indonesia, but also to many regions, including Surabaya in East Java province. Surabaya, as the capital city of the province, became the center of mobilizations of some theological puritans and political Islamists ${ }^{38}$ groups frequently involved in several protests such as FPI, HTI, and IKADI. ${ }^{39}$ These three groups initiated mass protests in the city. Yet, similar to Jakarta-based protests, while other Muslim roups such as NU and Muhammadiyah prefered to stay put, in a sense, some of their members decided to take part in the actions. Though the mass

\footnotetext{
35 "Ini Transkrip Lengkap Ucapan Ahok di Kepulauan Seribu," https://www.edunews.id/news/politik/ini-transkrip-lengkap-ucapan-ahok-di-kepulauan-seribu.

36 Interview with deputy of chairman PWNU East Java on 14 December 2018.

${ }^{37}$ Pamungkas et. al, "Aksi Bela Islam, p. 68.

${ }^{38}$ For the lack of precise category, these two terms are used at once to represent groups that protested Ahok's blasphemous statement. The terms are borrowed from Abdullah Saeed's typology. See his book entitled Islamic Thought: An Introduction (London and New York: Routledge, 2006), pp. 142-148.

39 “Massa Ormas Islam Jatim Demo Minta Ahok Dipejarakan," https://www.tribunnews.com/regional/2017/05/08/massa-ormas-islam-jatim-demo-minta-ahok-dipenjarakan.
} 
mobilization was as not as massive as those in Jakarta, the actions in Surabaya simply indicated how religious (Islamic) terms are fairly strategic in influencing and inspiring the mobilization of Islamic mass organizations especially in response to religious blasphemy cases.

In relation to this, an interesting fact appear dealing with the involvement of Muslim roups in most cases of religious blasphemy as most Muslim groups share common comprehension in interpreting blasphemy. Thus, whenever the practice of blasphemy occur, they unite and move together. They conduct simultaneous actions of rejection and demand for legal prosecution. This type of Muslim groups often shows militancy; not only condemn or criticize, but also carry out fierce demonstration which mostly ended in riot and many other anarchic actions. Nevertheless, some organizations are abstain from mass protests. They prioritize the settlement in a familial manner, and discussion. Conversely, some other organizations are resistant.

In relation to this, we see how Muslim groups s show different reactions towards the religious blasphemers. HTI and FPI indicated resistant as well as militant style. Moreover, according to some studies, both organizations tend to be radical. ${ }^{40}$ They tend to understand Islamic text as it is to digest all kinds of issues including political issue. Whereas, NU and Muhammadiyah are more likely to prioritize harmony and legal processes. These two different attitudes raised important questions of which answer is desperately needed immediately: about their construction in responding certain issues and about the understanding of blasphemy. As it is possible that the differences in response to blasphemy are closely related to their understanding of the meaning of blasphemy.

In general, based on empirical study, the construction of religious blasphemy in relation to Muslim groups in East Java is categorized into two. First, some Muslim groups literally refer to religious texts in responding blasphemous acts. For this particular group, blasphemy occurs when a group or individual commits a disgraceful act towards Islam and / or religious activities of Islam. Blasphemy against Islam is efforts to descredit a particular religion, to persecute the religion and its groups, intentionally or unintentionally. ${ }^{41}$ The main reference of such group is religious texts such as the Holy Qur'an and hadith which

\footnotetext{
40 Pamungkas et al, “Aksi Bela Islam, p. 69.

${ }^{41}$ Interview with the head of al-Irsyad Surabaya on 11 December 2017.
} 
are textually interpreted. ${ }^{42}$ Two Muslim groups of the Islamic Defenders Front (FPI) and Al-Irsyad belong to to this category.

For Al-Irsyad, in the context of life among religious believers, the term blasphemy is important to regulate inter-religious relations. ${ }^{43}$ However, blasphemy is still in need to have a definition. That way, Muslims who work in the field of da'wah and preach the message of monotheism but deliberately offend believers of other religions, will surely be considered as blasphemy. ${ }^{44}$ With this context, Al-Irsyad has a special view, that people of majority religion (Muslims) must be prioritized, and their aspirations must also be prioritized over than other religious minorities. This is not a form of intolerance. Islam has been able to survive due to this tolerant attitudes. Al-Irsyad will always uphold this spirit of unity (of Indonesia) on this basis. ${ }^{45}$

Nevertheless, though this Muslim group puts forward theological elements in interpreting blasphemy actions, they still uphold legal aspects, but in lesser emphasis. Their attitudes in favor of theological aspects makes this group have the simplistic majority-minority approach; the tendency to identify themselves as a majority group while other religious groups are called a minority group. This approach directly leads to an unbalanced relationship as they will present dominative actions, including matters of religious discourses. Unfortunately, in a democratic context, it is irrelevant due to their discriminating values. In addition, this group also has strong militant spirit in the name of Islamic religion. The spirit is manifested in their attitude to always use narrow religious perspective when viewing sociopolitical issues. For them, religions and politics has no demarcation, religion must be used as point of reference for anything including politics. Islam deals with all aspects of human life. This is the Islam way for every Muslim.

In relation to this political aspect, FPI believes that religion can be included into political dimension, but not the other way around, including politics into religious dimension. As they believe that presenting religion in politics is to uphold the interest of religion. That is the sole purpose of politics. They believe that Islam has its own

\footnotetext{
42 Interview with the head of FPI Pamekasan on 11 January 2018.

${ }^{43}$ Interview with the head of al-Irsyad Surabaya on 11 December 2017.

${ }^{44}$ Interview with the head of al-Irsyad Surabaya on 11 December 2017.

45 Interview with the head of al-Irsyad Surabaya on 11 December 2017.
} 
concept on politics, how politics is implemented, and in context politics must be applied. This is called siyasah. ${ }^{46}$ As a reference, this group refer to the political role of Prophet Muhammad. Prophet Muhammad also played a pivotal political role both in Mecca and Medina. Prophet Muhammad taught Muslims to actively participate to manage the country as part of religious duties. FPI consider that Muslims should be politically active. Passive involvement of Muslim community in politics will allow minority groups to dominate the Indonesian politics which will eventually make Muslims excluded. ${ }^{47}$

The second group is Muslim groups that appreciate legal establishment of the state. Unlike previously mentioned group, in addition to religious conviction, these groups also emphasized the use of a positive legal perspective in interpreting blasphemy. They value the positive law due to their views that Indonesian is neither a religious country nor the secular one. Indonesia has a distinct ideology named Pancasila in which its first precept is the oneness of God. ${ }^{48}$ Hence, philosophically, though the affirmation of Islam is not clearly stated, the relationship among believers of many religions in Indonesia has been long regulated. Therefore, matters concerned with blasphemy are included. Otherwise, cases beyond regulation are irrelevant as it will surely attract response apparently contradictive to law. ${ }^{49}$ The groups of its kinds are several Muslim groups such as MUI, Muhammadiyah, and NU.

Moreover, Indonesia Ulama Council (MUI) as an institution in charge of issuing fatwa has referred to the Law No. 1/PNPS/1965 on Abuse and/or Religious Blasphemy then confirmed through the Decision of Constitutional Court Number 140 / PUU-VII / 2009 dated April 19, 2010, as well as the Decision on criminal acts against religion in the Criminal Code, Articles 155, 156a, 175, 176, 177, 503, 530, 545, 546 and 547. The regulations clearly prohibit each individual to insult, abuse, harass or defame any religion in Indonesia. Thus, when actions of religious defamation arise, the individuals or groups

\footnotetext{
46 Interview with the head of FPI Pamekasan on 11 January 2018.

${ }^{47}$ Interview with the head of FPI Pamekasan on 11 January 2018.

48 Interview with deputy Muhammadiyah East Java on 27 December 2017.

${ }^{49}$ Interview with deputy Muhammadiyah East Java on 27 December 2017.
} 
will be legally processed as religious blasphemers then will be brought to court. ${ }^{50}$

Likewise, Muhammadiyah personalities show similar attitude on this issue. They consider blasphemy as an act of contradicting the thawabit (principles or fundamental tenets) of religion. ${ }^{51}$ Examples of thawabit in Islam include the existence and oneness of God, the existence of angels, the prophethood of Muhammad, the five-time daily prayer, zakah (obligatory alms), the obligation of hajj pilgrimage, prohibition of adultery, etc. Though in some cases, these elements are debatable, each religion obviously has different religious doctrine and dogma. Thus, debatable matters should be resolved by the existing law in Indonesia, as clearly regulated in the constitution. Ahok blasphemous case falls into this category. Its nature is debatable since there are various meanings to the word wali in the verse 51 of chapter al-Maidah of the Holy Quran.

NU also has its own understanding of religious practice. In general, NU implements the same principle as other Muslim groups in a way that denouncing religion refers to actions containing elements of disgrace towards religion and religious practice. The religious context refers to fundamental, basic and substantial matters in the religion. For instance, Islam considers some actions as religious blasphemy when they closely relate to the God oneness (taw מ̧id), the holy book, Muhammad's prophethood, and other principles. Interpreting the Holy Al-Qur'an at own convenience without authority or profound knowledge of it ${ }^{52}$ as committed by Ahok is also considered blasphemy, but a mild one. In addition, more extreme blasphemy might be indicated through declaration confirming that messages in particular religious scriptures as human fabrication like what Salman Rushdi stated in his "The Satanic Verses". In similar manner, portraying the facial image of the Prophet Muhammad as conducted by the french Magazine, Charlie Hebdo is considered blasphemy since such an act is strictly forbidden Islam.

Nonetheless, NU has different perception on blasphemy compared to other Muslim groups. Degrees of carefulness should be applied in examining a religious blasphemy rather than immediately

\footnotetext{
${ }^{50}$ Interview with Secretary of MUI East Java on 12 December 2017.

51 Interview with Deputy Muhammadiyah East Java on 27 December 2017..

52 Interview with Deputy NU East Java on 14 December 2017.
} 
putting it into legal process. NU will not carelessly draw conclusions refering to only a single religious text. In this regard, NU has different ways of understanding blasphemy.

First, each case of religious blasphemy is purely based on a religious point of view before it become the subject of legal process. No other elements should intervene religious examination, especially when it is concerned with political domain. In relation to Ahok's case, political veneer was more dominant than the blasphemy itself. For this reason, NU strongly emphasizes the importance of caution so that the defamation runs within a proper context, free from conflict of political interests. 53

Secondly, NU has its own point of view that blasphemy is not a single term to be identified against all forms of ill-treatment dealing with Islam. Thus, religious blasphemy is the most-tolerated treatment against religion. Another three more qualities of blasphemy are on the list such as defamation, harassment, humiliation, and hostility. ${ }^{54}$ As treated as the most tolerated action, blasphemy cases genarally can be resolved properly. Thus, those who are proven guilty, Basuki Tjahaja Purnama in this case, must be willing to admit their mistakes and make public apology. This way, NU considers that no further actions needed especially when it involves mass mobilization as it may ruin national unity. However, public apology does not mean getting rid of legal process. The law shlould always be implemented as it should be.

\section{Conclusion}

Religious blasphemy happened now and then in Indonesia. This article confirms that blasphemy is a word that the public use especially when pragmatic political logic, formal law, and religious interpretation collide. The abuse of religious narrative for political purposes turns to ignite profane problems and conflicts rather than upholding religious sacred texts. As a result, emotional actions are triggered and enabled people to force the religious blasphemers to justice. The Ahok case has been so precisely illustrative. It ripped apart the solidarity and tolerance of Muslims in Indonesia. While this particular issue builds social actions in the form of solidarity and collectivity of mass organizations throughout Indonesia, it also stimulated debate among Muslim groups

\footnotetext{
53 Interview with deputy NU East Java on 14 December 2017.

${ }^{54}$ Interview with deputy NU East Java on 14 December 2017.
} 
in Indonesia. After MUI issued that fatwa against Basuki Tjahaja Purnama for his blasphemous statement, Muslim groups split into two. In Surabaya, East Java, such a polarization does occur. The supporters of MUI fatwa, such as FPI and HTI tends to have textual, normative with Islamic political reference. They accused Ahok as aggressively violating Islamic law and causing Muslims uncomfortable with his statement and that is why he should send to prison. Whereas NU and Muhammadiyah in Surabaya have a more moderate theological construction in the consideration on the case of Ahok. This case does not belong to a major case of blasphemy since it does not concern the fundamental aspect of Islam. Yet, it belongs to a form of misconduct towards Islam. Then Ahok, thus, is not labeled as a serious but tolerated religious blasphemer, so that, with his misconduct, he simply requires to apologizes to Muslims. Apparently, the national political attitudes of NU and Muhammdiyah that put more concern on tolerance towards religious diversity is more dominant than political identity which result in intolerance to observers of other religions.]

\section{References}

\section{Books and Articles}

"41 Penista Agama Divonis Lima Tahun", https://nasional.tempo.co/read/107062/41-penista-agama-divonis-lima-tahun, 6 September 2007.

"Ahok Divonis Dua Tahun Penjara, Ini Komentar Jokowi". https://nasional.kompas.com/read/2017/05/09/17032111/ah ok.divonis.dua.tahun.penjara.ini.komentar.jokowi, 9 May 2017.

"Ini Transkrip Lengkap Ucapan Ahok di Kepulauan Seribu". https://www.edunews.id/news/politik/ini-transkrip-lengkapucapan-ahok-di-kepulauan-seribu, posted on 14 October 2016.

"Massa Ormas Islam Jatim Demo Minta Ahok Dipejarakan". https://www.tribunnews.com/regional/2017/05/08/massaormas-islam-jatim-demo-minta-ahok-dipenjarakan, 8 May, 2017

Alfan, Ahsanul. "Gerakan Tentara Kanjeng Nabi Muhammad (TKNM) Tahun 1918”. Jurnal Avatara, 4, 3 (October 2016).

Aminah, Siti, et. al, "Pemantauan Kasus-Kasus Penodaan Agama di Indonesia Periode 2012-2014”, Jurnal Keadilan Sosial, V (2015). 
Cammack, M. “Islamic Law In Indonesia's New Order". International and Comparative Law Quarterly, 38 (1989).

Conover, M. D., J. Ratkiewicz, M. Francisco, B. Goncalves, and A. Flammini. Political Polarization on Twitter. Proceedings of the Fifth International AAAI Conference on Weblogs and Social Media, 2011.

Dahri, Muhammad, "Tindak Pidana Penodaan Agama di Indonesia: Tinjauan Pengaturan Perundang-undangan dan Konsep Hukum Islam". Jurnal at-Tafahum. 1, 2 (July-December 2017).

Dubljević, V. Autonomy is Political, Pragmatic, and Postmetaphysical: A Reply to Open Peer Commentaries on "Autonomy in Neuroethics". AJOB Neuroscience, 7, 4 (2016).

Hasyim, Syafiq. "Majelis Ulama Indonesia and pluralism in Indonesia". Philosophy \& Social Criticism, 41, 4-5 (2015).

Haynes, J "Religion and international relations in the 21 st century: conflict or co-operation?". Third World Quarterly, 27, 3 (2006).

Hikmat, Mahi M. "Kebebasan Pers Kaitannya dengan Penodaan Terhadap Martabat Agama”. Jurnal al-Tsaqâfa, 9, 1 (June 2012).

James I. Lengle, Diana Owen, and Molly W. Sonner "Divisive Nominating Mechanisms and Democratic Party Electoral Prospects". Sonner Source: The Journal of Politics, 57, 2 (May 1995).

Jassin, HB. Heboh Sastra 1968: Suatu Pertanggungjawaban. Jakarta: Gunung Agung, 1970.

Kusumo, Rangga, and Hurriyah. "Populisme Islam di Indonesia: Studi Kasus Aksi Bela Islam oleh GNPF-MUI Tahun 2016-2017”. Jurnal Politik, 4, 1 (2018).

Lewis, Bradley. "The Biopsychosocial Model and Philosophic Pragmatism: Is George Engel a Pragmatist?”. Philosophy, Psychiatry, \& Psychology, 14, 4 (2007).

Majelis Ulama Indonesia, Pendapat Dan Sikap Keagamaan Majelis Ulama Indonesia Terkait Pernyataan Basuki Tjahaya Purnama, https://mui.or.id/berita/10590/pendapat-dan-sikap-keagamaan-mui-terkait-pernyataan-basuki-tjahaja-purnama/, 20 February 2017 
Marshall, Paul. "The Ambiguities of Religious Freedom in Indonesia". The Review of Faith \& International Affairs. 16, 1 (2018).

Ministry of Religious Affairs Republic Indonesia, Alqur'an dan Terjemahnya. Madinah Al Munawwarah: Mujammma' Al-Malik Fahd Li Thiba At Al Mush-haf Asy-Syarif, 1993.

Mudzhar, M. Atho. "The Legal Reasoning and Socio-Legal Impact of the Fatwãs of the Council of Indonesian Ulama on Economic Issues". Abkam, 13, 1 (January 2013).

Nurdin, Nazar. "Delik Penodaan Agama Islam di Indonesia". Jurnal Ibya Ulum Al-Din, 19, 1 (2017).

Osa, M. "Creating Solidarity: the Religious Foundations of the Polish Social Movement". East European Politics \& Societies, 67 (1997).

Saeed, Abdullah. Islamic Thought: An Introduction. London and New York: Routledge, 2006.

Setyaningrum, Arie Pamungkas and Gita Octaviani. "Aksi Bela Islam dan Ruang Publik Muslim: Dari Representasi Daring ke Komunitas Luring”. Jurnal Pemikiran Sosiologi, 4, 2 (August 2017).

Shiraishi, Takashi. Zaman Bergerak Radikalisme Rakyat di Jawa 1912-1926. Jakarta: Pustaka Utama Grafiti, 1997.

Soekanto, Soerjono. Mengenal Tujuh Tokoh Sosiologi. Jakarta: Rajawali Pers, 2002.

Susanti, Martien Herna. "Menguatkan Karakter Kebangsaan Indonesia di Era Globalisasi”. Prosiding Seminar Nasional PKn-Unnes, 2017.

Wahyuningtias, Arum. "Upaya HB. Jassin dalam Penyelesaian Polemik Heboh Sastra Cerpen 'Langit Makin Mendung' Karya Kipanjikusmin di Majalah Sastra Tahun 1968-1970". Jurnal Avatara, 3, 2 (July 2015).

Wehr, Hans. A Dictionary of Modern Written Arabic. Ithaca: Spoken Language Services, inc, 1976.

Woodward, Mark R. "The Slametan: Textual Knowledge and Ritual Performance in Central Javanese Islam”. History of Religions, 28, 1 (1988).

Yasmeen, Samina. "Pakistan, militancy and identity: parallel struggles". Australian Journal of International Affairs, 67, 2 (2013). 
M. Syamsul Huda

\section{Interviews}

Interview with the vice head of PWNU East Java on 14 December 2018.

Interview with the head of al-Irsyad Surabaya on 11 December 2017.

Interview with deputy Muhammadiyah East Java on 27 December 2017.

Interview with Secretary of MUI East Java on 12 December 2017.

Interview with Deputy PWNU East Java on 14 December 2017 at 11.00 WIB.

Interview with Deputy of Ministery of Religious Affairs, East Java on 16 December 2017. 